This article was downloaded by: [130.132.123.28]

On: 02 J anuary 2015, At: 06: 19

Publisher: Routledge

Informa Ltd Registered in England and Wales Registered Number: 1072954

Registered office: Mortimer House, 37-41 Mortimer Street, London W1T

3J H, UK

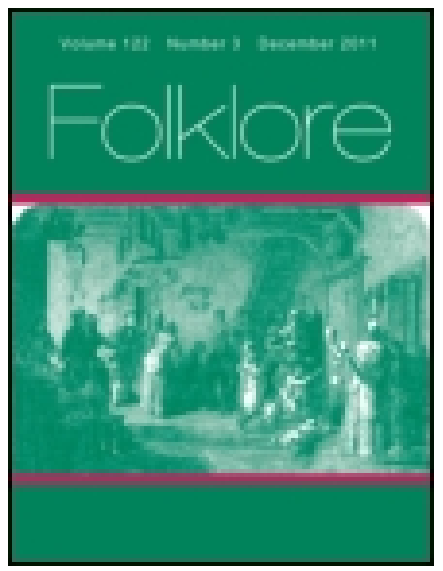

\title{
Folklore
}

Publication details, including instructions for authors and subscription information:

http:// www. tandfonline.com/loi/ rfol20

\section{Some Notes on the Physique, Customs, and Superstitions of the Peasantry of Innishowen, Co. Donegal}

Thomas Doherty

Published online: 14 Feb 2012.

To cite this article: Thomas Doherty (1897) Some Notes on the Physique, Customs, and Superstitions of the Peasantry of Innishowen, Co. Donegal, Folklore, 8:1, 12-18, DOI: 10.1080/0015587X.1897.9720395

To link to this article: http:// dx. doi.org/ 10.1080/0015587X.1897.9720395

\section{PLEASE SCROLL DOWN FOR ARTICLE}

Taylor \& Francis makes every effort to ensure the accuracy of all the information (the "Content") contained in the publications on our platform. However, Taylor \& Francis, our agents, and our licensors make no representations or warranties whatsoever as to the accuracy, completeness, or suitability for any purpose of the Content. Any opinions and views expressed in this publication are the opinions and views of the authors, and are not the views of or endorsed by Taylor \& Francis. The accuracy of the Content should not be relied upon and should be independently verified with primary sources of information. Taylor and Francis shall not be liable for any losses, actions, claims, proceedings, demands, costs, expenses, damages, and other liabilities whatsoever or howsoever caused arising directly or indirectly in connection with, in relation to or arising out of the use of the Content.

This article may be used for research, teaching, and private study purposes. Any substantial or systematic reproduction, redistribution, reselling, loan, sub-licensing, systematic supply, or distribution in any form to anyone is 
expressly forbidden. Terms $\&$ Conditions of access and use can be found at http://www.tandfonline.com/page/terms-and-conditions 


\section{2 The Physique, Customs, and Superstitions}

of the persistence of the most primitive modes of thought beneath the surface of our civilisation. Thank you for bringing it to my notice. . . .

\section{Yours very truly,}

James G. Frazer.

Short notes on "Straw Goblins" and "Marks on Ancient Monuments" (see pp. 87, 86), by Mr. C. G. Leland, were read; and some observations upon the latter were offered by Mr. Gomme, Mr. Naake, and Dr. Gaster.

Mr. L. Goldmerstein read a paper entitled "The Part played by Water in Marriage Customs" (see p. 84). In the discussion which followed, Dr. Gaster, Messrs. Gomme and Nutt, and the President took part.

A paper on the "Customs of the Peasantry of Innishowen," by Mr. Thomas Doherty of Carndonagh, was read by the President. A discussion followed, in which Messrs. Nutt, Higgens, and Kirby took part.

\section{SOME NOTES ON THE PHYSIQUE, CUSTOMS, AND SUIERSTITIONS OF THE PEASANTRY OF INNISHOWEN, CO. DONEGAL.}

BY THOMAS DOHLRTY.

Hair.-Along the seaboard districts, the prevailing colour of the hair among men and women is red, light red, or sandy. Many assert that this is to be attributed to some peculiar action of the sea air, the salt water, the diet (chiefly fish), or the employment. Most of the people in these places are engaged in outdoor pursuits, in all seasons and in all weathers-principally agriculture and fishing. I rather think that hereditary influences are the prevailing causes. The inhabitants are mostly descendants of the old Celtic tribes, pretty tall, strongly made, of straight long visage, 
with high cheek-bones. A few English and Scotch, said to be descendants of the planters of James I. and Elizabeth, are found among them; but these are of an entirely different cast of countenance, with blue or black eyes and black hair, except where they or their fathers have intermarried with the aborigines. In that case, the children of such have a tendency to the traditional florid features and red hair of the Celt. As we come inland, red hair is but seldom met with. Very few are bald.

Eyes.-The colour of the eyes is blue or light blue, some few cases black, while inland it is grey or a mixture of grey and black. Spectacles are seldom used; the eyes retain their keenness and vigour unimpaired, or but slightly so, up till the age of seventy, eighty, and above. I know several instances where old men and women follow their avocations, in which good vision is very requisite, without the aid of glasses. Second-sight is quite common. They are a long-lived people. There is hardly a village where one may not find half-a-dozen old people whose average ages are near one hundred years.

Dress.-Chiefly made from the wool of the sheep, which the women in the long winter nights card, spin on the ordinary spinning-wheel, and have woven by the weavers here on the old hand-looms. These cloths are then dyed and sent to the tuck-mill (fulling-mill), where they are pounded together by large blocks of wood, and afterwards freed from greasiness by having a stream of water pass over them. To assist in this process, fuller's-earth or chamber-lye is used, largely the latter. These cloths are very warm, and even when soaked through, as they often are by the rains so frequent here, are hardly ever changed by the wearer, possessing a heat altogether unknown by the owners of more highly-finished and consequently costlier garments. Many of the people go barefoot, more especially during the summer months.

Diet.-Up to a few years ago tea was almost unknown. 


\section{I4 The Physique, Customs, and Superstitions}

Now it is largely used, often three and four times each day. In addition, potatoes, Jndian meal porridge, and large quantities of fish are consumed. Flesh-meat not common.

Customs.-In walking along the roads every one salutes every other one met, whether previously acquainted or otherwise. On entering any house where churning is going on the visitor is expected to bless the work either in the Irish or the English tongue. Irish is liked better. "Go m-beannuigid Dia an ba agus bainne" (God bless your cows and milk) is the usual salutation. To enter or leave without doing so is a sure indication of taking the butter away by supernatural means. Should one enter a house where the above work (churning) is going on, the visitor is expected to remain until the work is finished. If one's fire goes out (gets quenched) he cannot get a coal from his neighbour's without first bringing in two "turf" (peat) and placing them on the fire from which he wishes to get the coals. Doing contrary portends the taking away of all good luck. To lend salt brings bad luck. To meet a red-haired woman is a sure omen of misfortune. $\Lambda$ barefooted or a bareheaded woman means the same.

When in a boat, the fishermen would almost throw one overboard should he chance to whistle. They say whistling always presages a storm. There is no objection to singing. After the boat is launched and a few yards from the beach, every head is uncovered, the oars lie idle, and prayers are said for a minute or two. A stranger never forgets this scene. Nothing appears more solemn. The long stretch of pebbly beach, the heaving waves, the rugged crags and serrated rocks around, the wide and boundless ocean outside, the little cockleshells, as the boats seem, bobbing up and down, and then not a murmur is heard except the swish of the waves or the sharp scream of the gull. All is silent as a churchyard, and there in the boat the crew, clad in oilskins, with faces bronzed by wind and weather, pleading with clasped hands and upturned eyes to the God of the tempest. 
Crowing hens are a certain sign of coming evils. When such happens, the unfortunate biped is quickly decapitated. A cock crowing before twelve o'clock (midnight) foretells similar ills.

In using the kidneys of animals slaughtered for meat, one person must consume all (both kidneys); should two or more share in them, a lump of flesh of a like size would, it is believed, be certain to grow on some part of the body, generally the face.

Hare-lip is common. If a woman be enceinte on meeting a hare, the child on being born has very often the upper lip disfigured by a split resembling the nosemark on the animal referred to. It is called hare-shagh. Some get the doctor to perform an operation on the child.

Cozes shot by the Fairies.-This does not happen to bulls or bullocks. The animal is all right in the morning or at night, and a few hours after is found to be all covered with little lumps, on pressing which with the fingers great pain is caused to the animal. The limbs, too, are partially paralysed. Some old man in the district, who is said to have influence with the spirits (fairies), is sent for. He places three little lumps of gunpowder on the animal's back-one on the top of the shoulders, one in the middle of the back, and one near the tail. These he explodes with a match; then a seton is put into the animal, or a red string tied round the tail. Some peculiar drink or mash is then given, and in a short time the animal is all right.

King's Evil (scrofula). - This is said to be cured by the touch of a seventh son, to be applied seven successive mornings before the sun rises, the patient to be fasting. No fee can be given or taken, or the cure fails.

Wens (warts). - These are removed by rubbing with the water found by chance in a hollow stone by the wayside. But the patient must not be on the search for such a stone.

Mumps.-Children suffering from mumps are cured by passing them three times back and forward under the belly 


\section{I6 The Physique, Customs, and Superstitions}

of a she-ass. Another remedy is to lead the boy or girl affected with the disease to a south-running stream, in branks. Branks are a kind of wooden bridle used for cattle in country districts.

Sprains or Broken Limbs.-These are cured by charms, which consist in touching the injured part with the hands and reciting some formulae in words.

Evil Eye.-Many persons here are supposed to have an "Evil Eye"-red-haired women in particular. Any animal except an ass, even a child looked upon by these persons, is said to be blinked, or under the influence of the "Evil Eye," and so will pine away and die.

Superstitions as to Fish.-Formerly Lough Suille(Swilly), an inlet of the sea, twenty-five miles in length and ten miles from Londonderry, on which Bunerana is built, was the great centre of the herring-fishing industry here. Hundreds of boats were to be found engaged in that pursuit; and often, the old men say, the beach was strewed with tons and tons of the fish-no market being had. At the beginning of the present century the witches of Scotland, possessing superior powers to those of the Irish, came over and enticed the finny denizens of the lough to Scotland. Since that time very few herrings are caught in the lough. It is told that the fishermen were engaged as usual. The night was very calm. Here, there, and everywhere was the lough dotted with boats with their crews. Up from the entrance of the inlet was seen rushing a silver herring of a large size. Quickly it rushed through the waters, passing by the boats with their outstretched nets. Up one side it rushed, followed by countless multitudes of herrings, away across, then down the other side, its following still increasing, until, having gathered all the herrings in its train, it swept away down the lough with a roar and rush resembling that of a mighty whirlwind. The fishermen, speechless with terror, rowed quickly ashore, minus their nets, and herring-fishing on Lough Suille became a thing of the past. 
In Clonmany, a district extending from Malin to Lough Suille, is a river in which salmon and trout are never found, though these fish abound in the neighbouring streams. To prove this, some individuals managed to capture several from a river alongside, and placed them in the one mentioned, but they immediately died. The reason given is that Columkille, the patron saint of Donegal, being on his travels in the district, and wearied and hungry, came upon some boys who had a fire kindled on the banks of the stream, in which they were roasting some trout caught from it. The saint asked for some to satisfy his hunger, but the boys refused to share the repast. Saint Columkille then pronounced a malediction, and told them that never again would a trout or salmon be found in the stream. Others tell that the saint had with him a goat which sup. plied him with milk during his wanderings, that the boys were out fishing, and coming on the animal, which was browsing on the rocks at some distance from where Columkille lay sleeping, they killed it, and making a fire cooked it, eating all but the hoofs and horns. The saint was so enraged on awakening and finding out what had happened, that he cursed the stream and the place.

Witches.-These (human or devil) are said to be not uncommon around here. Old women principally follow the avocation, oftentimes changing themselves into hares and roaming around during night-time or by daybreak, visiting their neighbours' byres (cow-houses), from which they are able by some mysterious power to take with them the milk and butter. Some of these witches of higher powers have no need to transform themselves, but are able by the aid of a peculiar hair-rope-made from the mane of a stallion in which there is not a single white hair-and the recital of some queer incantations to effect their object. Baeltine, or May-eve, is the only day in the year for weaving these spells and making the fetters. On several occasions these witches in the form of hares have been shot at, but without vol. vin. 
success. The only thing that can injure them is a silver bullet made from a sixpence or a shilling. I have heard that where they have been wounded by such fired from a gun, instead of the ordinary lead-pellets, on following up the wounded animal it was found in the form of a woman, seated with injured arm or leg in the corner of her own dwelling-house.

Old horse-shoes nailed inside doors are quite common. They are said to act as a preventive against the spells of the witches. When churning, the tongs are put in the fire, or a piece of heated iron is put under the churn, and kept there till the operation is finished. Also a piece of hairrope is sometimes put round the vessel. Several times have I heard men and women complain that they might churn for days but could get no butter, owing to the spells of the witches. The buttermilk ton was frothy and fulsome in taste and smell, and could not be used.

\section{TUESDAY, DECEMBER 16th, 1896.}

The President (Mr. Edward Clodd) in the Chair.

THE minutes of the last gencral meeting were read and confirmed.

The resignation of Lady Lewis, Mr. T. Heath Joyce, and Mr. Ulrico Hoepli were reported.

The election of the following new members was announced: Miss E. Wills, Miss Jessic L. Weston, Mrs. Sidgwick, Professor W. P. Ker, Mr. G. G. Traherne, Mr. A. Macgregor, Mr. S. G. Asher, Mr. L. Goldmerstein.

Miss M. Ffennell exhibited ( 1 ) a charm of invulnerability, (2) a witch charm, offensive and defensive, and (3) a pair of shears and mangala stand used in the tonsorial rite, all from Siam; and a short explanatory paper written by her (sec p. 88) was read by the President. 